\title{
SEX DETERMINATION USING PROXIMAL HAND PHALANGES
}

\author{
Fotios Alexandros Karakostis ${ }^{1}$, Eleni Zorba ${ }^{2}$, \\ Konstantinos Moraitis ${ }^{2}$ \\ ${ }^{1}$ Senckenberg Center for Human Evolution and Palaeoenvironments, \\ Eberhard Karl University of Tübingen, Germany \\ ${ }^{2}$ Department of Forensic Medicine and Toxicology, School of Medicine, \\ University of Athens, Greece
}

\begin{abstract}
Sex determination is among the most important biological data to be obtained from human skeletal remains. In anthropological sciences, the applied methodology involves the analysis of the quantitative and qualitative characteristics of skeletal parts. Measurements of proximal hand phalanges have been shown to exhibit prominent sexual dimorphism, in different populations examined. The aim of this study is to assess the utility of proximal hand phalanges for the sex diagnosis and develop a discriminant formula to be applied to Modern Greek populations. The material utilized consists of 661 proximal hand phalanges (left and right) from the Athens Collection, corresponding to 160 adult individuals (86 males and 74 females). Classification accuracies ranged between $94.6 \%$ and $100 \%$ for left and between $87.7 \%$ and $100 \%$ for right proximal phalanges. The results of this study indicate that proximal hand phalanges can be used for accurate sex diagnosis.
\end{abstract}

Keywords: forensic anthropology, sex determination, hand phalanges, Athens collection

\section{INTRODUCTION}

In anthropological sciences, the term "sexual dimorphism" (SD) refers to the phenotypic differences between the bones of males and females of the same species. The fundamental importance of studying SD lies in the necessity 
of developing accurate methods for assessing sex from skeletal remains [1]. Indeed, the bibliography provides a plethora of publications on the development and appliance of sex diagnostic methods using pelvic and cranial features [2]. Recently, however, there is a growing trend towards sex determination from various parts of the skeleton, including hand bones, such as proximal phalanges [3-6].

Consequently, small bones are considered useful for sex assessment. That is often explained by their increased quantity in the field as well as by their small amount of external surface exposed to taphonomic alterations [7]. As a result, they could contribute to sex diagnosis of poorly preserved human remains. In forensic anthropology, they could assist in personal identification of decomposing or skeletonized bodies, while, in bioarchaeology, they could contribute to a more precise reconstruction of the demographic profile [4].

In the case of the skeletal remains recovered from different locations of Greece, bones have often been subjected to marked seasonal fluctuation as well as particular soil conditions (e.g. soil acidity). As a result, they are often found in a fragmentary state [8]. Therefore, the development of the sex determining methods using small and intact hand bones is of a great utility when analyzing skeletal remains from Greece. It is evident that hand phalanges consist of small, dense, and compact bones, with a small external surface. Thus, they are often found well-preserved [9].

Considering that the degree of SD differs among population groups, mathematical equations for sex diagnosis should be developed separately for each group. In fact, it is considered important to develop population-specific sex assessing methods for each anatomical part of the skeleton [10].

A recently conducted research utilized the biometric data of proximal hand phalanges for the purpose of quantifying SD from a Greek population sample [11]. Taking into consideration the bibliographical gap of similar research on proximal hand phalanges from Greece, the aim of this article is to assess the sexdetermining ability of the data presented in this previous study.

\section{MATERIAL AND METHODS}

The material used in this study consists of 160 documented adult skeletons (86 males and 74 females) from the Athens collection, exhumed from two cemeteries in the greater area of the city of Athens [12]. According to their profile, the deceased individuals originated from various regions of Greece and were mainly of a lower or middle socioeconomic status. The mean age for males is 58.49 years (range: 19-96 years) and for females is 59.12 (range: 20-99 years) [11]. Only the 
$41.31 \%$ of the expected specimens (661) were available for this study due to the fact that in most skeletons there were left and right proximal hand phalanges that were either missing or extensively damaged.

A total of seven measurements was taken on each bone, including the maximum length of the shaft (ML) and the antero-posterior and medio-lateral widths at the base (APWB and MLWB), the midshaft (APWM and MLWM), and the head (APWH and MLWH) $[3,6,13,14]$. However, several proximal hand phalanges exhibited the dimensions that were either damaged or pathologically altered. In these cases, only the intact dimensions of the bones were measured and included in the analysis.

In a previous study, a Student's independent samples t-test was run to quantify SD [11]. The authors of this study found that all variables presented a statistically significant degree of SD. In the present research, for the purpose of deriving sex assigning equations, stepwise discriminant function analysis (SDFA) was performed for each left and right proximal hand phalanx, using the IBM SPSS Statistics (IBM Inc., version 20 for Windows) software package. All seven measurements taken were utilized as independent variables. The SDFA was performed for the selection of the best-discriminating variables between males and females (Wilk's lambda). Left and right proximal hand phalanges were studied separately, due to the bilaterally asymmetrical SD reported in this sample [11]. Besides, bilateral asymmetry in proximal hand phalanges has been reported [14].

For this reason, twenty discriminant functions were used (Table 1). These functions were developed, in order to suggest sex assessing equations in the cases where a possible skeletal assemblage is incomplete (e.g. the presence of only the first proximal hand phalanx or fragments of several phalanges). Due to the fact that SDFA requires complete sets of data, each function analysis was carried out using individuals without missing values in the variables involved. Consequently, given that some phalanges (or phalangeal parts) were missing or not measurable, the number of individuals utilized varies among functions (Table 3).

Finally, a "leave one out classification" procedure was applied for the purpose of quantifying the accuracy rate of the original sample, as well as of the sample created by cross-validation [15]. 
Table 1. Stepwise discriminant function analysis of hand proximal phalanges (left and right) ${ }^{a}$

\begin{tabular}{|c|c|c|c|c|c|}
\hline Steps and variables entered & $\begin{array}{l}\text { Wilks' lambda } \\
\text { statistic }\end{array}$ & $\begin{array}{l}\text { Exact } F \\
\text { statistic }\end{array}$ & d.f. 1 & d.f. 2 & Sig. \\
\hline \multicolumn{6}{|c|}{$\begin{array}{l}\text { Function 1: All left hand proximal } \\
\text { phalanges }\end{array}$} \\
\hline APWB 3rd & 0.172 & 127.773 & 2 & 53.000 & 0.000 \\
\hline MLWH 1st & 0.148 & 99.474 & 3 & 52.000 & 0.000 \\
\hline APWM 1st & 0.126 & 888.139 & 4 & 51.000 & 0.000 \\
\hline MLWH 4th & 0.115 & 77.102 & 5 & 50.000 & 0.000 \\
\hline MLWB 1st & 0.105 & 69.426 & 6 & 49.000 & 0.000 \\
\hline MLWH 3rd & 0.097 & 75.698 & 6 & 49.000 & 0.000 \\
\hline MLWM 2nd & 0.089 & 70.187 & 7 & 48.000 & 0.000 \\
\hline MLWB 4th & 0.080 & 67.367 & 8 & 47.000 & 0.000 \\
\hline \multicolumn{6}{|l|}{$\begin{array}{l}\text { Function 2: All right hand } \\
\text { proximal phalanges }\end{array}$} \\
\hline MLWB 5th & 0.386 & 90.770 & 1 & 57.000 & 0.000 \\
\hline APWB 1st & 0.247 & 85.427 & 2 & 56.000 & 0.000 \\
\hline MLWB 3rd & 0.195 & 75.897 & 3 & 55.000 & 0.000 \\
\hline APWB 4th & 0.178 & 62.199 & 4 & 54.000 & 0.000 \\
\hline \multicolumn{6}{|l|}{$\begin{array}{l}\text { Function 3: Left hand proximal } \\
\text { phalanges of 1st ray }\end{array}$} \\
\hline MLWH 1st & 0.339 & 138.522 & 1 & 71.000 & 0.000 \\
\hline APWM 1st & 0.240 & 110.918 & 2 & 70.000 & 0.000 \\
\hline MLWM 1st & 0.215 & 84.164 & 3 & 69.000 & 0.000 \\
\hline \multicolumn{6}{|l|}{$\begin{array}{l}\text { Function 4: Left hand proximal } \\
\text { phalanges of } 2 \text { nd ray }\end{array}$} \\
\hline MLWM 2nd & 0.466 & 89.093 & 1 & 75.000 & 0.000 \\
\hline APWB 2nd & 0.396 & 56.432 & 2 & 74.000 & 0.000 \\
\hline \multicolumn{6}{|l|}{$\begin{array}{l}\text { Function 5: Left hand proximal } \\
\text { phalanges of 3rd ray }\end{array}$} \\
\hline APWB 3rd & 0.386 & 152.602 & 1 & 96.000 & 0.000 \\
\hline MLWM 3rd & 0.329 & 96.892 & 2 & 95.000 & 0.000 \\
\hline MLWH 3rd & 0.311 & 69.393 & 3 & 94.000 & 0.000 \\
\hline \multicolumn{6}{|l|}{$\begin{array}{l}\text { Function 6: Left hand proximal } \\
\text { phalanges of } 4 \text { th ray }\end{array}$} \\
\hline MLWM 4th & 0.520 & 83.866 & 1 & 91.000 & 0.000 \\
\hline APWB 4th & 0.427 & 60.428 & 2 & 90.000 & 0.000 \\
\hline
\end{tabular}




\begin{tabular}{|c|c|c|c|c|c|}
\hline Steps and variables entered & $\begin{array}{l}\text { Wilks' lambda } \\
\text { statistic }\end{array}$ & $\begin{array}{l}\text { Exact } F \\
\text { statistic }\end{array}$ & d.f. 1 & d.f. 2 & Sig. \\
\hline \multicolumn{6}{|l|}{$\begin{array}{l}\text { Function 7: Left hand proximal } \\
\text { phalanges of } 5 \text { th ray }\end{array}$} \\
\hline APWB 5th & 0.766 & 20.120 & 1 & 66.000 & 0.000 \\
\hline \multicolumn{6}{|l|}{$\begin{array}{l}\text { Function 8: Maximum length } \\
\text { measurements of left hand } \\
\text { proximal phalanges }\end{array}$} \\
\hline ML 3rd & 0.444 & 67.607 & 1 & 54.000 & 0.000 \\
\hline ML 1st & 0.363 & 46.455 & 2 & 53.000 & 0.000 \\
\hline ML 4th & 0.331 & 35.094 & 3 & 52.000 & 0.000 \\
\hline ML 5th & 0.303 & 29.338 & 4 & 51.000 & 0.000 \\
\hline \multicolumn{6}{|l|}{$\begin{array}{l}\text { Function 9: Head measurements } \\
\text { of left hand proximal phalanges }\end{array}$} \\
\hline MLWH 1st & 0.286 & 134.697 & 1 & 54.000 & 0.000 \\
\hline MLWH 3rd & 0.236 & 86.009 & 2 & 53.000 & 0.000 \\
\hline \multicolumn{6}{|c|}{$\begin{array}{l}\text { Function 10: Basis measurements } \\
\text { of left hand proximal phalanges }\end{array}$} \\
\hline MLWB 3rd & 0.318 & 115.739 & 1 & 54.000 & 0.000 \\
\hline APWB 3rd & 0.262 & 74.510 & 2 & 53.000 & 0.000 \\
\hline MLWB 1st & 0.230 & 58.038 & 3 & 52.000 & 0.000 \\
\hline MLWB 5th & 0.211 & 47.687 & 4 & 51.000 & 0.000 \\
\hline \multicolumn{6}{|l|}{$\begin{array}{l}\text { Function 11: Midshaft } \\
\text { measurements of left hand } \\
\text { proximal phalanges }\end{array}$} \\
\hline MLWM 1st & 0.254 & 158.388 & 1 & 54.000 & 0.000 \\
\hline APWM 1st & 0.196 & 108.789 & 2 & 53.000 & 0.000 \\
\hline \multicolumn{6}{|l|}{$\begin{array}{l}\text { Function 12: Right hand proximal } \\
\text { phalanges of 1st ray }\end{array}$} \\
\hline APWM 1st & 0.411 & 107.495 & 1 & 75.000 & 0.000 \\
\hline ML 1st & 0.339 & 72.089 & 2 & 74.000 & 0.000 \\
\hline \multicolumn{6}{|l|}{$\begin{array}{l}\text { Function 13: Right hand proximal } \\
\text { phalanges of } 2 \text { nd ray }\end{array}$} \\
\hline MLWB 2nd & 0.603 & 50.034 & 1 & 76.000 & 0.000 \\
\hline APWB 2nd & 0.573 & 27.987 & 2 & 75.000 & 0.000 \\
\hline \multicolumn{6}{|l|}{$\begin{array}{l}\text { Function 14: Right hand proximal } \\
\text { phalanges of 3rd ray }\end{array}$} \\
\hline MLWB 3rd & 0.468 & 100.006 & 1 & 88.000 & 0.000 \\
\hline APWB 3rd & 0.415 & 61.326 & 2 & 87.000 & 0.000 \\
\hline
\end{tabular}




\begin{tabular}{|c|c|c|c|c|c|}
\hline Steps and variables entered & $\begin{array}{l}\text { Wilks' lambda } \\
\text { statistic }\end{array}$ & $\begin{array}{l}\text { Exact } F \\
\text { statistic }\end{array}$ & d.f. 1 & d.f. 2 & Sig. \\
\hline \multicolumn{6}{|l|}{$\begin{array}{l}\text { Function 15: Right hand proximal } \\
\text { phalanges of } 4 \text { th ray }\end{array}$} \\
\hline MLWM 4th & 0.383 & 122.689 & 1 & 76.000 & 0.000 \\
\hline ML 4th & 0.314 & 82.073 & 2 & 75.000 & 0.000 \\
\hline APWB 4th & 0.297 & 58.331 & 3 & 74.000 & 0.000 \\
\hline \multicolumn{6}{|l|}{$\begin{array}{l}\text { Function } 16 \text { : Right hand proximal } \\
\text { phalanges of } 5 \text { th ray }\end{array}$} \\
\hline MLWB 5th & 0.547 & 60.535 & 1 & 73.000 & 0.000 \\
\hline APWB 5th & 0.499 & 36.188 & 2 & 72.000 & 0.000 \\
\hline \multicolumn{6}{|l|}{$\begin{array}{l}\text { Function 17: Maximum length } \\
\text { measurements of right hand } \\
\text { proximal phalanges }\end{array}$} \\
\hline ML 4th & 0.493 & 58.550 & 1 & 57.000 & 0.000 \\
\hline ML 1st & 0.371 & 47.518 & 2 & 56.000 & 0.000 \\
\hline \multicolumn{6}{|c|}{$\begin{array}{l}\text { Function 18: Head measurements } \\
\text { of right hand proximal phalanges }\end{array}$} \\
\hline MLWH 4th & 0.469 & 64.522 & 1 & 57.000 & 0.000 \\
\hline MLWH 1st & 0.382 & 45.387 & 2 & 56.000 & 0.000 \\
\hline \multicolumn{6}{|c|}{$\begin{array}{l}\text { Function 19: Basis measurements } \\
\text { of right hand proximal phalanges }\end{array}$} \\
\hline MLWB 5th & 0.386 & 90.770 & 1 & 57.000 & 0.000 \\
\hline APWB 1st & 0.247 & 85.427 & 2 & 56.000 & 0.000 \\
\hline MLWB 3rd & 0.195 & 75.897 & 3 & 55.000 & 0.000 \\
\hline APWB 4th & 0.178 & 62.199 & 4 & 54.000 & 0.000 \\
\hline \multicolumn{6}{|l|}{$\begin{array}{l}\text { Function 20: Midshaft } \\
\text { measurements of right hand } \\
\text { proximal phalanges }\end{array}$} \\
\hline APWM 1st & 0.417 & 79.818 & 1 & 57.000 & 0.000 \\
\hline MLWM 4th & 0.293 & 67.461 & 2 & 56.000 & 0.000 \\
\hline MLWM 5th & 0.274 & 48.674 & 3 & 55.000 & 0.000 \\
\hline
\end{tabular}

\section{RESULTS}

Table 1 shows the variables in each function that contributed to SDFA. Wilks' lambda is the criterion for variable selection. It is used to add or remove variables from the analysis. The p-value of Wilk's lambda was 0 in all cases, indicating a high degree of differentiation attribute of all the discriminant functions. The stepwise procedure is "guided" by the respective F to enter and F to remove 
values. The $\mathrm{F}$ value for a variable indicates its statistical significance in the discrimination between groups, i.e. it is a measure of the extent to which a variable makes a unique contribution to the prediction of group membership [16].

A comparison between functions 1 and 2 - where all the left and the right proximal phalanges were tested respectively - showed that more variables entered in the analysis of the left phalanges. In the left proximal hand phalanges (function 1), the measurements of the medio-lateral width at the head, basis and midshaft entered more frequently in the discriminant analysis than those of the equivalent antero-posterior width. Most variables entered from the 1st proximal phalanges, followed by these of the $3 \mathrm{rd}$ and the 4 th ray, with the APWB of the 3rd ray entered first in the SDFA. From the 5th ray, there were not any variables entered in the analysis. In the right proximal hand phalanges (function 2), only four of the variables entered in the SDFA and they all involved widths at the basis. Interestingly, the variable that entered first in the analysis is the MLWB of the 5th proximal phalanx.

In functions $3,4,5,6$, and 7 , where each left proximal phalanx was tested separately, the variable MLWM contributed to all functions, with the exception of function 7. In function 7, where only measurements of the 5th ray were tested, the only variable entered was APWB. The APWB also contributed to all functions, with the exemption of function 3.

In ML of the left proximal hand phalanges (function 8), the variables of almost all rays were entered, except for the ML of the 2 nd ray. In widths at the head, basis and midshaft of the left proximal phalanges (functions 9, 10, 11 ), the variables that contributed more to discriminant analysis involved the medio-lateral measurements.

In the right proximal hand phalanges (functions 12, 13, 14, 15, and 16), where each phalanx was tested separately, the variables that contributed most to discriminant analysis were the medio-lateral and antero-posterior measurements at the base. The ML of the proximal phalanx of the 1st and the 4th ray proved also important, contrary to the case of the equivalent proximal left phalanges. When ML and the widths at the head were tested separately (functions $17,18)$, only the variables of the 1 st and the 4 th ray entered in the analysis. However, in functions 19 and 20, only measurements of the 2nd finger did not contribute to the analysis.

Table 2 depicts unstandardized coefficients, the structure matrix, standardized coefficients, group centroids, and the sectioning point, for each function. The standardized coefficient shows the contribution of the respective variable to the 
discrimination between the two sexes. The structure matrix presents the correlations between the variables and discriminant functions. Group centroids are the mean discriminant score for each sex. These means can be used to determine the degree of separation between the two sexes. The sectioning point is the average of male and female group centroids. The unstandardized coefficient is used in the calculation of the discriminant function score $(\mathrm{Y})$.

Table 2. Canonical discriminant function coefficients for hand left and right proximal phalanges' groups

\begin{tabular}{|c|c|c|c|c|c|c|}
\hline \multirow[t]{2}{*}{ Functions } & \multirow{2}{*}{$\begin{array}{l}\text { Unstan- } \\
\text { dardized } \\
\text { coeffi- } \\
\text { cients }^{\mathrm{a}}\end{array}$} & \multirow{2}{*}{$\begin{array}{l}\text { Struc- } \\
\text { ture } \\
\text { matrix }^{b}\end{array}$} & \multirow{2}{*}{$\begin{array}{c}\text { Stan- } \\
\text { dardized } \\
\text { coeffi- } \\
\text { cients }\end{array}$} & \multicolumn{2}{|c|}{ Group centroids } & \multirow{2}{*}{$\begin{array}{l}\text { Sec- } \\
\text { tioning } \\
\text { point }^{c}\end{array}$} \\
\hline & & & & Male & Female & \\
\hline \multicolumn{7}{|c|}{$\begin{array}{l}\text { Function 1: All left } \\
\text { hand proximal pha- } \\
\text { langes }\end{array}$} \\
\hline APWB 3rd & 1.030 & 0.401 & 0.498 & 2.675 & -4.134 & -0.7295 \\
\hline MLWH 1st & 1.904 & 0.466 & 1.123 & & & \\
\hline APWM 1st & 2.926 & 0.429 & 1.010 & & & \\
\hline MLWH 4th & -0.900 & 0.189 & -0.721 & & & \\
\hline MLWB 1st & -0.881 & 0.338 & -0.681 & & & \\
\hline MLWH 3rd & -0.954 & 0.398 & 0.546 & & & \\
\hline MLWM 2nd & 0.679 & 0.301 & 0.408 & & & \\
\hline MLWB 4th & -0.622 & 0.265 & -0.494 & & & \\
\hline (constant) & -40.083 & & & & & \\
\hline \multicolumn{7}{|c|}{$\begin{array}{l}\text { Function 2: All right } \\
\text { hand proximal pha- } \\
\text { langes }\end{array}$} \\
\hline MLWB 5th & 0.682 & 0.588 & 0.404 & 2.005 & -2.220 & -0.1075 \\
\hline APWB 1st & 0.676 & 0.558 & 0.583 & & & \\
\hline MLWB 3rd & 0.531 & 0.513 & 0.465 & & & \\
\hline APWB 4th & 0.695 & 0.567 & 0.349 & & & \\
\hline (constant) & -34.149 & & & & & \\
\hline \multicolumn{7}{|c|}{$\begin{array}{l}\text { Function 3: Left } \\
\text { hand proximal pha- } \\
\text { langes of 1st ray }\end{array}$} \\
\hline MLWH 1st & 0.886 & 0.730 & 0.577 & 1.667 & -2.135 & -0.234 \\
\hline APWM 1st & 1.201 & 0.590 & 0.542 & & & \\
\hline MLWM 1st & 0.651 & 0.656 & 0.395 & & & \\
\hline (constant) & -24.510 & & & & & \\
\hline
\end{tabular}




\begin{tabular}{|c|c|c|c|c|c|c|}
\hline \multirow[t]{2}{*}{ Functions } & \multirow{2}{*}{$\begin{array}{l}\text { Unstan- } \\
\text { dardized } \\
\text { coeffi- } \\
\text { cients }^{\mathrm{a}}\end{array}$} & \multirow{2}{*}{$\begin{array}{l}\text { Struc- } \\
\text { ture } \\
\text { matrix }^{b}\end{array}$} & \multirow{2}{*}{$\begin{array}{l}\text { Stan- } \\
\text { dardized } \\
\text { coeffi- } \\
\text { cients }\end{array}$} & \multicolumn{2}{|c|}{ Group centroids } & \multirow{2}{*}{$\begin{array}{l}\text { Sec- } \\
\text { tioning } \\
\text { point }^{c}\end{array}$} \\
\hline & & & & Male & Female & \\
\hline \multicolumn{7}{|c|}{$\begin{array}{l}\text { Function 4: Left } \\
\text { hand proximal pha- } \\
\text { langes of } 2 \text { nd ray }\end{array}$} \\
\hline MLWM 2nd & 0.986 & 0.868 & 0.617 & 1.001 & -1.485 & -0.242 \\
\hline APWB 2nd & 1.098 & 0.835 & 0.557 & & & \\
\hline (constant) & -22.075 & & & & & \\
\hline \multicolumn{7}{|c|}{$\begin{array}{l}\text { Function 5: Left } \\
\text { hand proximal pha- } \\
\text { langes of 3rd ray }\end{array}$} \\
\hline APWB 3rd & 0.893 & 0.847 & 0.496 & 1.276 & -1.701 & -0.2125 \\
\hline MLWM 3rd & 0.585 & 0.759 & 0.385 & & & \\
\hline MLWH 3rd & 0.555 & 0.810 & 0.355 & & & \\
\hline (constant) & -23.422 & & & & & \\
\hline \multicolumn{7}{|c|}{$\begin{array}{l}\text { Function } 6 \text { : Left } \\
\text { hand proximal pha- } \\
\text { langes of } 4 \text { th ray }\end{array}$} \\
\hline MLWM 4th & 0.862 & 0.828 & 0.628 & 1.040 & -1.263 & -0.1115 \\
\hline APWB 4th & 1.013 & 0.807 & 0.595 & & & \\
\hline (constant) & -19.183 & & & & & \\
\hline \multicolumn{7}{|c|}{$\begin{array}{l}\text { Function 7: Left } \\
\text { hand proximal pha- } \\
\text { langes of } 5 \text { th ray }\end{array}$} \\
\hline APWB 5th & 1.701 & 1.000 & 1.000 & 0.441 & -0.670 & -0.1145 \\
\hline (constant) & -17.187 & & & & & \\
\hline \multirow{2}{*}{\multicolumn{7}{|c|}{$\begin{array}{l}\text { Function 8: Maxi- } \\
\text { mum length mea- } \\
\text { surements of left } \\
\text { hand proximal pha- } \\
\text { langes }\end{array}$}} \\
\hline & & & & & & \\
\hline $\begin{array}{l}\text { ML 3rd } \\
\text { ML 1st }\end{array}$ & $\begin{array}{l}0.590 \\
0.454\end{array}$ & $\begin{array}{l}0.738 \\
0.716\end{array}$ & $\begin{array}{l}0.889 \\
0.696\end{array}$ & 1.198 & -1.852 & \\
\hline $\begin{array}{l}\text { ML 1st } \\
\text { ML 4th }\end{array}$ & $\begin{array}{r}-0.448 \\
-0.48\end{array}$ & 0.475 & -0.799 & & & \\
\hline ML 5th & 0.393 & 0.540 & 0.418 & & & \\
\hline (constant) & -35.259 & & & & & \\
\hline
\end{tabular}




\begin{tabular}{|c|c|c|c|c|c|c|}
\hline \multirow[t]{2}{*}{ Functions } & \multirow{2}{*}{$\begin{array}{l}\text { Unstan- } \\
\text { dardized } \\
\text { coeffi- } \\
\text { cients }^{\mathrm{a}}\end{array}$} & \multirow{2}{*}{$\begin{array}{l}\text { Struc- } \\
\text { ture } \\
\text { matrix }^{b}\end{array}$} & \multirow{2}{*}{$\begin{array}{l}\text { Stan- } \\
\text { dardized } \\
\text { coeffi- } \\
\text { cients }\end{array}$} & \multicolumn{2}{|c|}{ Group centroids } & \multirow{2}{*}{$\begin{array}{l}\text { Sec- } \\
\text { tioning } \\
\text { point }\end{array}$} \\
\hline & & & & Male & Female & \\
\hline \multicolumn{7}{|c|}{$\begin{array}{l}\text { Function 9: Head } \\
\text { measurements of } \\
\text { left hand proximal } \\
\text { phalanges }\end{array}$} \\
\hline MLWH 1st & .194 & 0.877 & 0.704 & 1.423 & -2.199 & -0.388 \\
\hline MLWH 3rd & 0.893 & 0.749 & 0.511 & & & \\
\hline (constant) & -25.518 & & & & & \\
\hline \multicolumn{7}{|c|}{$\begin{array}{l}\text { Function 10: Basis } \\
\text { measurements of } \\
\text { left hand proximal } \\
\text { phalanges }\end{array}$} \\
\hline MLWB 3rd & 0.774 & 0.757 & 0.492 & 1.528 & -2.361 & -0.4165 \\
\hline APWB 3rd & 1.241 & 0.703 & 0.600 & & & \\
\hline MLWB 1st & 0.676 & 0.592 & 0.522 & & & \\
\hline MLWB 5th & -0.578 & 0.260 & -0.398 & & & \\
\hline (constant) & -30.636 & & & & & \\
\hline \multicolumn{7}{|c|}{$\begin{array}{l}\text { Function 11: Mid- } \\
\text { shaft measure- } \\
\text { ments of left hand } \\
\text { proximal phalanges }\end{array}$} \\
\hline MLWM 1st & 1.764 & 0.845 & 0.717 & 1.600 & -2.473 & -0.4365 \\
\hline APWM 1st & 1.593 & 0.717 & 0.550 & & & \\
\hline (constant) & -26.591 & & & & & \\
\hline \multicolumn{7}{|c|}{$\begin{array}{l}\text { Function 12: Right } \\
\text { hand proximal pha- } \\
\text { langes of 1st ray }\end{array}$} \\
\hline APWM 1st & 1.190 & 0.858 & 0.726 & 1.291 & -1.470 & -0.0895 \\
\hline ML 1st & 0.333 & 0.711 & 0.531 & & & \\
\hline (constant) & -18.203 & & & & & \\
\hline \multicolumn{7}{|c|}{$\begin{array}{l}\text { Function 13: Right } \\
\text { hand proximal pha- } \\
\text { langes of } 2 \text { nd ray }\end{array}$} \\
\hline MLWB 2nd & 0.761 & 0.939 & 0.713 & 0.875 & -0.831 & 0.022 \\
\hline APWB 2nd & 0.567 & 0.804 & 0.411 & & & \\
\hline (constant) & -18.968 & & & & & \\
\hline
\end{tabular}




\begin{tabular}{|c|c|c|c|c|c|c|}
\hline \multirow[t]{2}{*}{ Functions } & \multirow{2}{*}{$\begin{array}{l}\text { Unstan- } \\
\text { dardized } \\
\text { coeffi- } \\
\text { cients }^{\mathrm{a}}\end{array}$} & \multirow{2}{*}{$\begin{array}{l}\text { Struc- } \\
\text { ture } \\
\text { matrix }^{b}\end{array}$} & \multirow{2}{*}{$\begin{array}{l}\text { Stan- } \\
\text { dardized } \\
\text { coeffi- } \\
\text { cients }\end{array}$} & \multicolumn{2}{|c|}{ Group centroids } & \multirow{2}{*}{$\begin{array}{l}\text { Sec- } \\
\text { tioning } \\
\text { point }^{c}\end{array}$} \\
\hline & & & & Male & Female & \\
\hline \multicolumn{7}{|c|}{$\begin{array}{l}\text { Function 14: Right } \\
\text { hand proximal pha- } \\
\text { langes of 3rd ray }\end{array}$} \\
\hline MLWB 3rd & 0.642 & 0.898 & .569 & 1.148 & -1.200 & -0.026 \\
\hline APWB 3rd & 0.918 & 0.890 & 0.549 & & & \\
\hline (constant) & -21.629 & & & & & \\
\hline \multicolumn{7}{|c|}{$\begin{array}{l}\text { Function 15: Right } \\
\text { hand proximal pha- } \\
\text { langes of } 4 \text { th ray }\end{array}$} \\
\hline MLWM 4th & 0.904 & 0.826 & 0.553 & 1.518 & -1.518 & 0.000 \\
\hline ML 4th & 0.235 & 0.666 & 0.465 & & & \\
\hline APWB 4th & 0.638 & 0.722 & 0.323 & & & \\
\hline (constant) & -25.466 & & & & & \\
\hline \multicolumn{7}{|c|}{$\begin{array}{l}\text { Function 16: Right } \\
\text { hand proximal pha- } \\
\text { langes of 5th ray }\end{array}$} \\
\hline MLWB 5th & 0.912 & 0.908 & 0.631 & 0.901 & -1.086 & -0.0925 \\
\hline APWB 5th & 1.041 & 0.850 & 0.502 & & & \\
\hline (constant) & -23.770 & & & & & \\
\hline \multicolumn{7}{|c|}{$\begin{array}{l}\text { Function 17: } \\
\text { Maximum length } \\
\text { measurements of } \\
\text { right hand proximal } \\
\text { phalanges }\end{array}$} \\
\hline ML 4th & 0.349 & 0.778 & 0.653 & 1.217 & -1.347 & -0.065 \\
\hline ML 1st & 0.402 & 0.768 & 0.640 & & & \\
\hline (constant) & -27.056 & & & & & \\
\hline \multicolumn{7}{|c|}{$\begin{array}{l}\text { Function 18: Head } \\
\text { measurements of } \\
\text { right hand proximal } \\
\text { phalanges }\end{array}$} \\
\hline MLWH 4th & 1.202 & 0.836 & 0.674 & 1.189 & -1.317 & -0.064 \\
\hline MLWH 1st & 0.713 & 0.763 & 0.573 & & & \\
\hline (constant) & -22.007 & & & & & \\
\hline
\end{tabular}




\begin{tabular}{|c|c|c|c|c|c|c|}
\hline \multirow[t]{2}{*}{ Functions } & \multirow{2}{*}{$\begin{array}{l}\text { Unstan- } \\
\text { dardized } \\
\text { coeffi- } \\
\text { cients }^{\mathrm{a}}\end{array}$} & \multirow{2}{*}{$\begin{array}{l}\text { Struc- } \\
\text { ture } \\
\text { matrix }^{b}\end{array}$} & \multirow{2}{*}{$\begin{array}{c}\text { Stan- } \\
\text { dardized } \\
\text { coeffi- } \\
\text { cients }\end{array}$} & \multicolumn{2}{|c|}{ Group centroids } & \multirow{2}{*}{$\begin{array}{c}\text { Sec- } \\
\text { tioning } \\
\text { point }^{c}\end{array}$} \\
\hline & & & & Male & Female & \\
\hline \multicolumn{7}{|c|}{$\begin{array}{l}\text { Function 19: Basis } \\
\text { measurements of } \\
\text { right hand proximal } \\
\text { phalanges }\end{array}$} \\
\hline MLWB 5th & 0.682 & 0.588 & 0.404 & 2.005 & -2.220 & -0.1075 \\
\hline APWB 1st & 0.676 & 0.558 & 0.583 & & & \\
\hline MLWB 3rd & 0.531 & 0.513 & 0.465 & & & \\
\hline APWB 4th & 0.695 & 0.567 & 0.349 & & & \\
\hline (constant) & -34.149 & & & & & \\
\hline \multicolumn{7}{|c|}{$\begin{array}{l}\text { Function 20: Mid- } \\
\text { shaft measure- } \\
\text { ments of right hand } \\
\text { proximal phalanges }\end{array}$} \\
\hline APWM 1st & 1.099 & 0.726 & 0.648 & 1.522 & -1.685 & -0.0815 \\
\hline MLWM 4th & 0.638 & 0.701 & 0.407 & & & \\
\hline MLWM 5th & 0.740 & 0.656 & 0.372 & & & \\
\hline (constant) & -19.492 & & & & & \\
\hline
\end{tabular}

For sex assessment, it is necessary to create a mathematical equation, in order to produce the discriminant function score $(\mathrm{Y})$. For that purpose, the phalangeal measurements that were entered in each function should multiply with the respective unstandardized coefficients and the outcome should be added to the "constant". When the value of this calculation is above the sectioning point, the equations suggest that the individual is male, whereas if the value is below the sectioning point, then the individual is considered female. The form of the equation is:

$$
Y=b_{1}{ }^{\star} X_{1}+b_{2}{ }^{*} X_{2}+b_{3}{ }^{\star} X_{3}+\ldots+b_{i}{ }^{*} X_{i}+a
$$

where,

$b_{1}-b_{i}=$ regression coefficients (unstandardized coefficients)

$X_{1}-X_{i}=$ the value of each variable

$a=$ constant

$i=$ the number of predictor variables

The classification accuracy of each function is presented in Table 3 (the accuracies for the original groups, the cross-validated groups, and the total value from both 
sides and sexes). Remarkably, the accuracy rate of correct sex determination is extremely high, reaching 100\% when all phalanges are present (function 1 and 2 ) from the left or the right side. All estimations were based on the amount of cases in which our model gave the correct sex classification. In case where each finger was tested separately, the accuracy ranged between $88.2 \%$ and $97.3 \%$ for the left phalanges and between $84.6 \%$ and $92.2 \%$ for the right phalanges. The 1st proximal phalanges display the highest classification accuracy observed $(97.3 \%$ for the left 1 st phalanges and $92.2 \%$ for the right 1 st phalanges), while the lowest accuracy rate was obtained for the left 5 th proximal phalanges (88.2\%) and the right 2 nd proximal phalanges (84.6\%). The variables of the left phalanges presented higher classification accuracy rates than the equivalent right. In the functions that each measurement was tested separately (using all 5 proximal phalanges of each side), the classification accuracy rate ranged between $94.6 \%$ and $98.3 \%$ for the left phalanges and between $87.7 \%$ and $100 \%$ for the right phalanges. Additionally, in the same functions, the measurements of the left side gave better classification accuracies than those of the right side, with the exception of the widths at base. Among measurements, the widths at the head present the most accurate classification rate in the left proximal phalanges (98.3\%), whereas, in the right proximal phalanges, the widths at the base predict sex in the $100 \%$ of cases.

Table 3. Accuracy of classification results of the original and cross-validated samples

\begin{tabular}{|c|c|c|c|c|c|}
\hline \multirow[t]{3}{*}{ Functions } & \multicolumn{4}{|c|}{ Predicted group membership } & \multirow{3}{*}{$\begin{array}{c}\text { Total } \\
\text { average } \\
(\%)\end{array}$} \\
\hline & \multicolumn{2}{|c|}{ Male } & \multicolumn{2}{|c|}{ Female } & \\
\hline & $N$ & $\%$ & $N$ & $\%$ & \\
\hline \multicolumn{6}{|c|}{$\begin{array}{l}\text { Function 1: All left hand proximal } \\
\text { phalanges }\end{array}$} \\
\hline Original & $35 / 35$ & $100 \%$ & $24 / 24$ & $100 \%$ & $100 \%$ \\
\hline Cross-validated & $35 / 35$ & $100 \%$ & $22 / 24$ & $91.7 \%$ & $96.6 \%$ \\
\hline \multicolumn{6}{|c|}{$\begin{array}{l}\text { Function 2: All right hand proximal } \\
\text { phalanges }\end{array}$} \\
\hline Original & $32 / 32$ & $100 \%$ & $28 / 28$ & $100 \%$ & $100 \%$ \\
\hline Cross-validated & $31 / 32$ & $96.9 \%$ & $28 / 28$ & $100 \%$ & $98.3 \%$ \\
\hline \multicolumn{6}{|c|}{$\begin{array}{l}\text { Function 3: Left hand proximal } \\
\text { phalanges of 1st ray }\end{array}$} \\
\hline Original & $40 / 41$ & $97.6 \%$ & $31 / 32$ & $96.9 \%$ & $97.3 \%$ \\
\hline Cross-validated & $40 / 41$ & $97.6 \%$ & $30 / 32$ & $93.8 \%$ & $95.9 \%$ \\
\hline
\end{tabular}




\begin{tabular}{|c|c|c|c|c|c|}
\hline \multirow[t]{3}{*}{ Functions } & \multicolumn{4}{|c|}{ Predicted group membership } & \multirow{3}{*}{$\begin{array}{l}\text { Total } \\
\text { average } \\
(\%)\end{array}$} \\
\hline & \multicolumn{2}{|c|}{ Male } & \multicolumn{2}{|c|}{ Female } & \\
\hline & $N$ & $\%$ & $N$ & $\%$ & \\
\hline \multicolumn{6}{|c|}{$\begin{array}{l}\text { Function 4: Left hand proximal } \\
\text { phalanges of } 2 \text { nd ray }\end{array}$} \\
\hline Original & $43 / 46$ & $93.5 \%$ & $28 / 31$ & $90.3 \%$ & $92.2 \%$ \\
\hline Cross-validated & $42 / 46$ & $91.3 \%$ & $28 / 31$ & $90.3 \%$ & $90.9 \%$ \\
\hline \multicolumn{6}{|c|}{$\begin{array}{l}\text { Function 5: Left hand proximal } \\
\text { phalanges of 3rd ray }\end{array}$} \\
\hline Original & $54 / 56$ & $96.4 \%$ & $37 / 42$ & $88.1 \%$ & $92.9 \%$ \\
\hline Cross-validated & $54 / 56$ & $96.4 \%$ & $37 / 42$ & $88.1 \%$ & $92.9 \%$ \\
\hline \multicolumn{6}{|c|}{$\begin{array}{l}\text { Function 6: Left hand proximal } \\
\text { phalanges of } 4 \text { th ray }\end{array}$} \\
\hline Original & $46 / 51$ & $90.2 \%$ & $37 / 42$ & $88.1 \%$ & $89.2 \%$ \\
\hline Cross-validated & $45 / 51$ & $88.2 \%$ & $36 / 42$ & $85.7 \%$ & $87.1 \%$ \\
\hline \multicolumn{6}{|c|}{$\begin{array}{l}\text { Function 7: Left hand proximal } \\
\text { phalanges of } 5 \text { th ray }\end{array}$} \\
\hline Original & $37 / 41$ & $90.2 \%$ & $23 / 27$ & $85.2 \%$ & $88.2 \%$ \\
\hline Cross-validated & $37 / 41$ & $90.2 \%$ & $23 / 27$ & $85.2 \%$ & $88.2 \%$ \\
\hline \multicolumn{6}{|c|}{$\begin{array}{l}\text { Function 8: Maximum length } \\
\text { measurements of } \\
\text { left hand proximal phalanges }\end{array}$} \\
\hline Original & $32 / 34$ & $94.1 \%$ & $21 / 22$ & $95.5 \%$ & $94.6 \%$ \\
\hline Cross-validated & $31 / 34$ & $91.2 \%$ & $20 / 22$ & $90.9 \%$ & $91.1 \%$ \\
\hline \multicolumn{6}{|c|}{$\begin{array}{l}\text { Function 9: Head measurements of } \\
\text { left hand proximal phalanges }\end{array}$} \\
\hline Original & $35 / 35$ & $100 \%$ & $24 / 25$ & $96.0 \%$ & $98.3 \%$ \\
\hline Cross-validated & $35 / 35$ & $100 \%$ & $24 / 25$ & $96.0 \%$ & $98.3 \%$ \\
\hline \multicolumn{6}{|c|}{$\begin{array}{l}\text { Function 10: Basis measurements of } \\
\text { left hand proximal phalanges }\end{array}$} \\
\hline Original & $33 / 34$ & $97.1 \%$ & $20 / 22$ & $90.9 \%$ & $94.6 \%$ \\
\hline Cross-validated & $33 / 34$ & $97.1 \%$ & $20 / 22$ & $90.9 \%$ & $94.6 \%$ \\
\hline \multicolumn{6}{|c|}{$\begin{array}{l}\text { Function 11: Midshaft } \\
\text { measurements of } \\
\text { left hand proximal phalanges }\end{array}$} \\
\hline Original & $40 / 41$ & $97.6 \%$ & $30 / 32$ & $93.8 \%$ & $95.9 \%$ \\
\hline Cross-validated & $38 / 41$ & $92.7 \%$ & $28 / 32$ & $87.5 \%$ & $90.4 \%$ \\
\hline \multicolumn{6}{|c|}{$\begin{array}{l}\text { Function 12: Right hand proximal } \\
\text { phalanges of 1st ray }\end{array}$} \\
\hline Original & $36 / 41$ & $87.8 \%$ & $35 / 36$ & $97.2 \%$ & $92.2 \%$ \\
\hline Cross-validated & $36 / 41$ & $87.8 \%$ & $35 / 36$ & $97.2 \%$ & $92.2 \%$ \\
\hline
\end{tabular}




\begin{tabular}{|c|c|c|c|c|c|}
\hline \multirow[t]{3}{*}{ Functions } & \multicolumn{4}{|c|}{ Predicted group membership } & \multirow{3}{*}{$\begin{array}{l}\text { Total } \\
\text { average } \\
(\%)\end{array}$} \\
\hline & \multicolumn{2}{|c|}{ Male } & \multicolumn{2}{|c|}{ Female } & \\
\hline & $N$ & $\%$ & $N$ & $\%$ & \\
\hline \multicolumn{6}{|c|}{$\begin{array}{l}\text { Function 13: Right hand proximal } \\
\text { phalanges of } 2 \text { nd ray }\end{array}$} \\
\hline Original & $31 / 38$ & $81.6 \%$ & $35 / 40$ & $87.5 \%$ & $84.6 \%$ \\
\hline Cross-validated & $30 / 38$ & $78.8 \%$ & $35 / 40$ & $85.0 \%$ & $82.1 \%$ \\
\hline \multicolumn{6}{|c|}{$\begin{array}{l}\text { Function 14: Right hand proximal } \\
\text { phalanges of 3rd ray }\end{array}$} \\
\hline Original & $39 / 46$ & $84.8 \%$ & $42 / 44$ & $95.1 \%$ & $90.0 \%$ \\
\hline Cross-validated & $39 / 46$ & $84.8 \%$ & $41 / 44$ & $93.2 \%$ & $88.9 \%$ \\
\hline \multicolumn{6}{|c|}{$\begin{array}{l}\text { Function } 15 \text { : Right hand proximal } \\
\text { phalanges of } 4 \text { th ray }\end{array}$} \\
\hline Original & $36 / 39$ & $92.3 \%$ & $35 / 39$ & $89.7 \%$ & $91.0 \%$ \\
\hline Cross-validated & $35 / 39$ & $89.7 \%$ & $35 / 39$ & $89.7 \%$ & $89.7 \%$ \\
\hline \multicolumn{6}{|c|}{$\begin{array}{l}\text { Function } 16 \text { : Right hand proximal } \\
\text { phalanges of } 5 \text { th ray }\end{array}$} \\
\hline Original & $36 / 41$ & $87.8 \%$ & $28 / 34$ & $82.4 \%$ & $85.3 \%$ \\
\hline Cross-validated & $35 / 41$ & $85.4 \%$ & $28 / 34$ & $82.4 \%$ & $84.0 \%$ \\
\hline \multicolumn{6}{|c|}{$\begin{array}{l}\text { Function 17: Maximum length } \\
\text { measurements of right hand } \\
\text { proximal phalanges }\end{array}$} \\
\hline Original & $33 / 34$ & $97.1 \%$ & $27 / 31$ & $87.1 \%$ & $92.3 \%$ \\
\hline Cross-validated & $32 / 34$ & $94.1 \%$ & $27 / 31$ & $87.1 \%$ & $90.8 \%$ \\
\hline \multicolumn{6}{|c|}{$\begin{array}{l}\text { Function 18: Head measurements of } \\
\text { right hand proximal phalanges }\end{array}$} \\
\hline Original & $30 / 34$ & $88.2 \%$ & $27 / 31$ & $87.1 \%$ & $87.7 \%$ \\
\hline Cross-validated & $30 / 34$ & $88.2 \%$ & $26 / 31$ & $87.1 \%$ & $86.2 \%$ \\
\hline \multicolumn{6}{|c|}{$\begin{array}{l}\text { Function 19: Basis measurements of } \\
\text { right hand proximal phalanges }\end{array}$} \\
\hline Original & $32 / 32$ & $100 \%$ & $28 / 28$ & $100 \%$ & $100 \%$ \\
\hline Cross-validated & $31 / 31$ & $96.9 \%$ & $28 / 28$ & $100 \%$ & $98.3 \%$ \\
\hline \multicolumn{6}{|c|}{$\begin{array}{l}\text { Function 20: Midshaft } \\
\text { measurements of } \\
\text { right hand proximal phalanges }\end{array}$} \\
\hline Original & $29 / 32$ & $90.6 \%$ & $27 / 28$ & $96.4 \%$ & $93.3 \%$ \\
\hline Cross-validated & $29 / 32$ & $90.6 \%$ & $25 / 28$ & $89.3 \%$ & $90.0 \%$ \\
\hline
\end{tabular}


The "leave one out classification" procedure compares the accuracies between the original sample and the one created by cross-validation. It should be mentioned that there are slight differences between the accuracy rates (misclassification of 1 or 2 individuals); which result, however, to non-significant lowering of the predictive potential of the discriminant function equations. The accuracies of the cross-validated sample remain in all cases over $82 \%$, a very high percentage of correct classification.

\section{DISCUSSION}

The results of the SDFA indicate that proximal hand phalanges are very useful bones for a highly accurate assessment of sex in Greek populations. Indeed, there were functions in which the accuracy rate reached $100 \%$. This performance can be justified by the high degree of SD (reached $24.78 \%$ ) reported for our population sample [11].

The difference between the accuracy rates of the left and the right proximal hand phalanges may be due to various patterns of lifelong physical activity. In bones, physical stress is considered to be mainly responsible for both SD and bilateral asymmetry. Due to the fact that upper limbs are used for less uniform activities than the lower limbs, they often present a higher degree of SD and bilateral asymmetry [17].

In literature, there have been numerous studies on sex determination using hand bones, such as the metacarpals [3, 18-20]. Concerning proximal hand phalanges, however, there are few researches investigating sex determination. Among them, some utilize multiple functions from all ten proximal hand phalanges $[4,6]$ while others focus on specific phalanges or phalangeal dimensions $[3,5,21]$. Due to the fact that most functions selected vary among studies, a direct comparison was rarely possible.

Scheuer and Elkington [3] conducted a research on a sample of 60 individuals from the United Kingdom. Their published discriminant equations for sex diagnosis using 1st proximal phalanges produced accuracy rates between $74 \%$ and $78 \%$. Case and Ross [5] studied the ML of proximal phalanges in a sample of 259 skeletons from the Terry Collection. The discriminant equations that derived from their data provided an accuracy of $80.8 \%$ using the ML of all left proximal hand phalanges [1-5] and an accuracy of $83.1 \%$ using all right proximal hand phalanges [1-5].

Smith ([4] conducted a research on the hand bones of 40 individuals of Black and White ancestry from the United States. In her research, she used 
multiple functions that provided the classification rates that ranged between $81.88 \%$ and $94.38 \%$ for the left proximal phalanges and between $83.02 \%$ and $90.57 \%$ for the right proximal phalanges. Navsa [6] developed discriminant equations for sex determination using proximal phalanges of 200 Black and White individuals from South Africa. Classification accuracies ranged between $83.2 \%$ and $86.4 \%$. The highest accuracies were obtained for the 1 st $(86.4 \%)$ and the $3 \mathrm{rd}(84.8 \%)$ proximal hand phalanges, whereas the lowest accuracy was reported for the 2 nd proximal phalanges (83.2\%). Among measurements, the highest classification accuracies were obtained for the APWM and the MLWM ( $86.4 \%$ and $85 \%$, respectively). Finally, a recent study on a Thai population of 249 individuals provided discriminant function equations for sex assessment. Correct classification rates ranged from $87.6 \%$ to $92.3 \%$, with left 1 st proximal phalanges presenting the highest accuracy (92.3\%), followed by the left $2 \mathrm{nd}$ proximal phalanges (91.9\%) [21].

In our research, in functions using all five phalanges from each side, the discriminant equations provided classification accuracies ranging between $94.6 \%$ and $98.3 \%$ in the left proximal phalanges and between $87.7 \%$ and $100 \%$ in the right proximal phalanges. The left and the right 1st proximal phalanges presented the highest classification accuracy ( $97.3 \%$ and $92.2 \%$ respectively), whereas the lowest accuracy was obtained for the 2nd right proximal phalanges (84.6\%). The two functions involving ML of either all left (1-5) or all right (1-5) proximal hand phalanges provided successful classification in the $94.6 \%$ and $92.3 \%$ of cases respectively. Among measurements, the widths at the head of the left phalanges and at the base of the right phalanges provided the highest classification accuracies ( $98.3 \%$ and $100 \%$, respectively).

However, it should be mentioned again that, as described in the material and methods section, each function is based on a different number of specimens (Table 3). This is due to the fact that the SDFA requires complete sets of data, while many proximal hand phalanges were either missing or damaged. As a result, the functions using multiple rays of left or right proximal hand phalanges $[1,2,8,9$, $10,11,17,18,19$, and 20] were represented by less individuals (ranging between 22 and 41 specimens for each sex) than those functions based on isolated left or right bones (ranging between 27 and 56 specimens for each sex). Indeed, all of the latter functions involved - at all times - over 31 individuals in each sex, with the exemption of the seventh one that utilizes female left 5 th proximal foot phalanges (27 individuals). Consequently, the functions based on single rays rely on more powerful samples. 
Furthermore, it should be noticed that the excellent accuracy rates (100\%) of three functions -1, 2, and 19- present slight drop after cross-validation (96.6\%, $98.3 \%$, and $98.3 \%$ respectively). This suggests that, even though the accuracy of these three functions using multiple rays is extremely high, it should not be expected to be flawless. Nevertheless, given that the SDFA utilizes the best-discriminating variables between males and females, the functions involving multiple bones (thus more variables) are indeed more possible to provide more accurate sex discrimination than those based on a single ray.

In bones, physical activity is a major factor for SD. Through the process of bone remodeling, width dimensions are subjected to size transformations that occur during early life, puberty, and adulthood. As a result, the degree of SD reported is influenced by the particular social and occupational background of male and female individuals composing the sample. Concerning bone length, most development is completed before adulthood. In that case, the biological origin of a population sample is a restrictive factor in developing and using mathematical equations for sex determination [22].

Consequently, SD is directly affected by secular and biological factors. Therefore, it is vital to derive mathematical sex-assessing equations for each population group analyzed [23]. Until present, there are no other studies on sex determination using proximal hand phalanges from Greece.

The results of our research suggest highly accurate equations for sex diagnosis using proximal hand phalanges. In forensic anthropology, these linear discriminant function equations could be very useful when other major bones are missing from the skeletal remains found. Moreover, phalanges consist of small and compact bones, which are often preserved intact in the field. ${ }^{7}$ In addition, they could also prove useful in bioarchaeology and for that reason the accuracy of the proposed equations should be further tested on archaeological skeletal populations. Besides the contribution of sex assessment in ancient demographics, the analyses of gender-specific occupational stress-markers in proximal hand phalanges could set the basis for speculations on sexual distribution of labor in societies of the past $[24,25]$.

\section{REFERENCES}

1. Cox M., Mays S. (2006). Human Osteology. Cambridge University Press, Cambridge.

2. Krogman W.M., İșcan M.Y. (1986). The human skeleton in forensic medicine. 2nd ed. Charles C Thomas, Springfield. 
3. Scheuer J.L., Elkington N.M. (1993). Sex determination from metacarpals and the first proximal phalanx. J Forensic Sci, 38, 769-778.

4. Smith S.L. (1996). Attribution of hand bones to sex and population groups. J Forensic Sci, 41, 469-477.

5. Case D.T., Ross A.H. (2007). Sex determination from hand and foot bone lengths. J Forensic Sci, 52, 264-270.

6. Navsa N. (2010). Skeletal morphology of the human hand as applied in forensic anthropology. PhD Thesis. University of Pretoria, Pretoria.

7. Byers S., Akoshima K., Curran B. (1989). Determination of adult stature from metatarsal length. Am J Phys Anthropol, 79, 275-279.

8. Mountrakis C., Eliopoulos C., Koilias C.G., Manolis S.K. (2010). Sex determination using metatarsal osteometrics from the Athens collection. Forensic Sci Int, 200, 178.e1-178.e7.

9. Lyman R.L. (1994). Vertebrate taphonomy. Cambridge University Press, New York.

10. Wolpoff M.W., Frayer D.W. (1985). Sexual dimorphism. Annu Rev Anthropol, 14, 429-473.

11. Karakostis F.A., Zorba E., Moraitis K. (2015). Sexual dimorphism of proximal hand phalanges. Int. J. of Osteoarchaeol. 25, 733-742.

12. Eliopoulos C., Lagia A., Manolis S.K. (2007). A modern, documented human skeletal collection from Greece. HOMO - J Comp Hum Biol, 58, 221-228.

13. Marzke M.W., Shrewsbury M.M., Horner K.E. (2007). Middle phalanx skeletal morphology in the hand: can it predict flexor tendon size and attachments? Am J Phys Anthropol, 134, 141-151.

14. Varas G., Thompson T.J.U. (2011). Metric dimensions of the proximal phalanges of the human hand and their relationship to side, position, and asymmetry. HOMO - J Comp Hum Biol, 62, 126-143.

15. Kranioti E.F., İşcan M.Y., Michalodimitrakis M. (2008). Craniometric analysis of the modern Cretan population. Forensic Sci Int, 180, 110.e1-110.e5.

16. Hill T., Lewicki P. (2006). Statistics: methods and applications: a comprehensive reference for science, industry, and data mining. Statsoft Inc, Tulsa.

17. Kennedy K.A.R. (1989). Skeletal markers of occupational stress. In: İşcan M.Y., Kennedy K.A.R. (eds.) Reconstruction of life from the skeleton. Wiley-Liss, New York, 129-160.

18. Lazenby R.A. (1994). Identification of sex from metacarpals: effect of side asymmetry. J Forensic Sci, 39, 1188-1194.

19. Falsetti A.B. (1995). Sex assessment from metacarpals of the human hand. J Forensic Sci, 40, 774-776.

20. Manolis S.K., Eliopoulos C., Koilias C.G., Fox C.F. (2009). Sex determination using metacarpal biometric data from the Athens Collection. Forensic Sci Int, 193, 130.el-130.e6. 
21. Mahakkanukrauh P., Khanpetch P., Prasitwattanseree S., Case D.T. (2013). Determination of sex from the proximal hand phalanges in a Thai population. Forensic Sci Int, 226, 208-215.

22. Rauch F. (2005). Bone growth in length and width: the yin and yang of bone stability. J Musculoskelet. Neuronal Interact, 5, 194-201.

23. Bario P.A., Trancho G.J., Sanchez J.A. (2007). Metacarpal sexual determination in a Spanish population. J Forensic Sci, 52, 264-270.

24. Frayer D.W. (1980). Sexual dimorphism and cultural evolution in the Late Pleistocene and Holocene of Europe. J Hum Evol, 9, 399-415.

25. Ruff C. (1987). Sexual dimorphism in human lower limb bone structure: relationship to subsistence strategy and sexual division of labor. J Hum Evol, 16, 391-416.

\section{Address for correspondence to:}

Fotios Alexandros Karakostis

Senckenberg Center for Human Evolution and Palaeoenvironments

Eberhard Karl University of Tübingen

Rumelinstrasse 23

Tübingen 72070, Germany.

E-mail: afkarakostis@hotmail.com 